\title{
Creating comedy in satiric short stories by means of language tools
}

\author{
Bakyt Aitbaeva - Mukhamedkali Abduov - Kamhsat Tuleubaeva - Marina \\ Zhunusova - Almagul Ametova
}

DOI: 10.18355/XL.2018.11.02.31

\begin{abstract}
This article describes semantic features of humorous literature. Thus, we have analyzed works written by Kazakh satirists. It was established that expressiveevaluative connotation involves information about the object evaluation. Evaluation is made in terms of positive and negative emotions. One can note that irony and humor created by Kazakh satirists are expressed by words with the opposite meaning and polysemantic word-play. The authors can use direct and associative meaning of formal and informal pronouns. In the analyzed linguistic passages represented by lexical and contextual antonyms, phonetic rhymes, amplification synonyms and rhetorical questions, convergence clearly shows an evaluation contrast between a character and the author.
\end{abstract}

Keywords: satire, features of artistic expression, stylistic contrast, phraseological combinations

\section{Introduction}

Satire is a technique employed by writers to criticize reality for the purpose of its improvement (Hodgart 2017). Satire appeared in antiquity as a social structure. Therefore, it is considered as a social phenomenon (Rapport, Stade 2014; Svebak 2014). Each literary artist chooses the most convenient form to gain knowledge of reality. Humor is regarded as one of that forms used to gain aesthetic knowledge of reality. The funny side of any situation is based on the elements of humor, irony, and satire. Comedy is created by using linguistic and extra linguistic tools (Bramlett 2012).

Russian scientists (M. M. Bakhtin, L. N. Timofeev, Yu. B. Borev, B. Dziemidok, D. N. Nikolaev) consider the humorous situation as the basis of satire. The following linguists: V. V. Vinogradov, A. I. Efimova, L. A. Bulahovskogo, A. A. Slonim, E. A. Zemskaya, V. N. Vakurova, F. I. Vinogradova, G. S. Pokrass and B. Korzhova, in turn, suggest that linguistic and poetic features of comedy might ground the genre.

I. V. Arnold, E. V. Maksimenko, V. V. Ovsyannikov, V. A. Solovyan, S. I. Pochodne, F. Artemov and G. Tremasova might find the features of using semantic systems to be their research subject.

It is appropriate to cite the statement made by the famous scientist $\mathrm{T}$. Makeeva, who devoted his works to satire. According to him, satire must involve intonation manifestations of strong feelings, scathing vocabulary for concealed mockery and open ridicule, sarcasm and irony. Secondly, there must be certain prerequisites for this.

The satirist deliberately overdraws or twists events and facts of reality, emphasizes their importance, and thus, draws public attention to them by using patterns and bringing the intrigue into the story, making ambiguous conclusion. In this regard, we shall mention the famous dictum introduced by V. Belinsky: Language is the most varied palette in literature. The narrative is the most important thing for language. The language is simple and comprehensible for the ordinary reader, so it is valuable and lives forever. 
This statement is essential for satire as an important part of the literature. In the case of satire, circumstances that cause laughter are the most important condition, but it's only a beginning. In fact, the art of satire is defined by its descriptive language and presentation style.

Satire is not limited to only one genre. Its elements can be found in many works: in prose and poetry, plays, poems, and stories.

In literary theory, irony means to ridicule and mockery while sarcasm - a sharp expression with a sarcastic condemning tone. According to K. Zhumaliyeva, laughter is the root for all. We ridicule or laugh at someone or at certain moments of life. If there's irony and mockery, then it is forwarded as a sort of arrogance and bragging. Sarcasm, on the contrary, is served without cover. Its language is sharp and prickly. Thus, irony and sarcasm are common for all genres.

Over-detailed description of events reduces the artistic value and richness of satirical works. It is another matter if the event is interesting and attractive. Satirist's language should be reflected in style. According to T. Karakeev, satirist should describe any event or human action through own writing style while the tone of bitter laughter should not be on the lips of any character.

In some satire, one can found few stylistic structures at the same time: author's description, self-abusing character, dialogue and parody. This technique allows enhancing the expressiveness, creating contrast and finding new combinations. Satire is a peculiar stylistic trend that requires a suitable, harmonious combination of sound. For example, choice principle supporters prefer grotesque, hyperbole, cartoons, sarcasm, irony and satire as a means of expression.

According to the Handbook of Literary Encyclopedia: satire (from Latin: satira mixture) is an element of comedy characterized by sharp criticism and ridicule over malice.

The linguistic expression for satire, humor, and irony, is determined by the presence of laughter that is difficult to identify. It should be noted that language of comedy as a complex phenomenon has no specific definition.

A. Salikhova, the researcher studying the concepts of humor in Kazakh linguistics, argues that funny narrative is manifested in a specific form - as a different kind of comedy.

Satire cannot exist outside the laughable incident, as the latter is not only a means of satire, but its goal as well. Hence, satire and comedy are obviously related.

In the Handbook, irony is introduced as another variety of comedy.

One can note that young Kazakh writers, poets, playwrights, and satirists have clearly expressed their position in life and their point of view on paper, and thereby, drew the attention of readers and literary critics. Various research works written by linguists and literary critics were devoted to the creativity of pen masters in the context of stylistics, linguistics, and General Philology. Each author was considered as a research subject in ideological and aesthetic terms. This is understandable since artistic language presentation is forming the style of each author. Linguistic analysis performs an important function in determining the role of artwork in the literary process and artistic language. The main purpose of the linguistic analysis is to reveal author's ideas and his/her style by showing different linguistic data (facts), his/her personal attitude to the events he/she is describing and by clarifying the meanings of specific words, namely:

1) obsolete words and phrases, especially lexicological and phraseological archaisms and historicism (semantic archaisms);

2) unclear data hidden in poetic symbols;

3) periphrases;

4) dialects, specific phrases, slang and terms;

5) semantics and basic words considered as artistic unity with specific content. 
Each artist chooses simple words that would help to understand the described reality. Comedy is a means of this aesthetic description. Comedy is created mainly with such concepts as humor, irony, and satire. It is represented through linguistic and extra-linguistic means. According to researchers, basic factors of fun are the following: extended meanings and word use; affectation; stylistic contrast arising from using words in a variety of stylistic features; credibility; using the word in situational and contextual aspects. In the latter case, the author is focused on the relationship and dialogue between the dialog partners; event circumstances (data described in the text); on describing characters, their speech peculiarity. This pattern is typical for satirist's work.

\section{Results}

Kazakh satirists express irony and humor by using words with the opposite meaning and polysemantic word-play, as well as components of phraseological combinations in contrast with other words in microtexts. For example, O. Imanaliyev's short story called the Smooth Nerves is based on the contradiction with a popular folk expression - exhausted nerves. The story is written in the style of speech association and rhymes (no great nerves were like tattered cloth; late and drunk), metaphors (playing the fool; making a storm; I push and hear the ring crying), periphrasis - stylistic units, where the idea has been conveyed by many stylistic methods (he didn't comb his thick black hair, he had even no idea what this process was like; saying bad things; having long ears) (Arnold 2002).

In the short story called The Golden Watch, writer highlights the contradiction between a golden watch and the lost golden time, skillfully making the readers laugh. Particular words, found in the text, have multiple and expressive meanings through the word-play. In the context, word-play is one of the effective methods for creating comedy. In word-play, associative perception is the most important thing. It is characterized by its aesthetic function. The author not only makes the readers laugh by using word-play but affects their mood and emotions (Potapova, Potapov 2014: 113-122). Logically, word-play has been created by means of convergence, comparison or equation of monosemantic words in terms of humor (Salikhova 2001: 14).

Many writers use words in direct and associative meaning, for example: lucky ticket, unique position, old flu. The latter can be defined as an occasional practice, because expressions used in spoken language, such as long lasting flu, well-known flu, were intentionally changed in order to make fun of the character (Attardo, Raskin 2017).

In satirical short stories included in the Sealed Envelope and the Pair of Galoshes collection books, T. Kozhakeev (1996) brings into focus the variety of people's bad habits, such as: predatory attitude to public property, the negative influence of human relationships in society. The writer openly raises a laugh against negative social phenomena, such as greed, sycophancy, impermanence, drinking, materialism, gossips. The writer criticizes the mentioned negative phenomena by dividing them into several groups: the Lonely Stake, the Examples of Lonely Stake, the Couplets of Lonely Stake, the Ninety Steps of Toban, and the Balpan's Heights.

In the Sealed Envelope, many words (names) are given in quotation marks. Since this method is used to give an opposite meaning, any reader will find a lot of fun: the Save from Mizir, The Candidate, and the Satiety. In the short story called The Candidate, comedy is created by means of polysemanticism. Not knowing the meaning of the word candidate, Balpan invited a scientist to his house, pursuing his own objectives. It turned out, that the scientist selected an ordinary fly as a subject for his research. Balpan could not understand the subject matter, despite the scientist's

XLinguae, Volume 11, Issue 2, April 2018, ISSN 1337-8384, eISSN 2453-711X 
attempts to explain it to him. Naturally, Balpan lost his interest to the candidate, and the author quasi understands his indifference. According to Balpan: concluded.

Whatever you may say, but being a "candidate" is not an easy job, - he

Don't make the "candidate" angry, otherwise everybody will be in trouble.

The true character of Balpan is disclosed by means of author's remark. We should note that the minor character is called Someone, Somebody without particular lexicological meaning. This stylistic method demonstrating biased attitude and disregard is used in this case to express views of the character and the author regarding the servility established in society (Simpson, Bousfield 2017).

The next short story is based on a famous sententia of Abay. It is about people wasting their time. Such an attitude to life has eventually led to bad consequences gossips. The issue, initially perceived as something new, slowly turned into the subject of gossip, into idle talking. Kodebay, who came to his native village with good thoughts, remains disappointed at the end. In fact, his good expectations do not match with the reality established in the village. This contradiction (effect of failed expectations) eventually leads to consequences that cause only laughter.

T. Kozhakeev (1996) has many characters speaking for themselves: Balpan, Zhotan, Toban. The cycle of satirical stories titled as the Ninety Steps of Toban catches the interest of readers. The author widely uses emotional and expressive lexical units to reveal the character and reality images. Predicates making a parallel between one another form a composed syntactic construction in the past tense: crowd of people standing in front of the café began to grow; mouths of sitting people started to move; cheekbones creak, throats gurgle. Then, all this started to fall down through well-esophagus into the pit-stomach.

In satirical stories, T. Kozhakeev (1996) criticizes harmful social and human phenomena. It is clear that human being and society as a part of a social institution cannot live apart. That is why such negative phenomena become a subject of an evil laughter. T. Kozhakeev (1996) raises various issues of his time, such as:

- greed, flattery, fancy talk, gossips, hypocrisy, gluttony, parsimony;

- theft of public property, corruption.

Abay has pointed out five problems of his time: gossip, lie, laziness, boasting, and prodigality. Let's return to our characters... In the short story called the Men Vist, someone, who is considered as a friend of Talpak Tanatarov, tells about some circumstance similar to the situation mentioned by Abay: A bad friend is in sight under the clear sky, but you do not see him once the clouds gather overhead. His friends are just waiting for the right moment to save themselves. Based on the story told by Talpak Tanatarov's friend, we can clearly see the true faces his friends have: You see, Talpak Tanatarov, who was respected by all of us, suddenly flew off his position, for which these sycophants were crawling around him. Besides idle rumors and fairy tales for children, we have never heard such a cynic gossip spread around.

The writer has demonstrated the significance of Talpak Tanatarov's job position by skillfully using extended epithet and emotional power.

The phraseological unit flew off has enhanced the dynamism in characters' actions. In the second sentence, double words (in Kazakh) are given together with amplification synonyms (identical definitions used for word expression): idle rumors and fairy tales are synonyms in lexicographical formation, but in the context, each of them has a stylistic function. In terms of their semantic characteristics, these words are adjectives with similar meanings.

The author uses national phraseological units in the story; some phrases are used without change while some of them have undergone occasional change. We can also trace contamination. For example:

- Who knows what it will be at the end... He used to be a proud man, but now he is like he was castrated - so melted down. 
- Comparing to us, who were like the right eye and the left pocket for him, Ontay will be Talpak's nephew and the Chief.

- Anyway, we are not that useless and stupid...

- A trader lives like in paradise, but he should not forget about the hell, where he will be burnt...

The above phraseological units belong to different stylistic groups. Phraseological units castrated and melted down (in Kazakh) are used without semantic changes. The following examples: the right eye and the left pocket (in Kazakh) can be considered as occasional phraseological units. In spoken language, right eye is used with a positive meaning, but in this context, it is negatively colored. The left pocket is an additional unit (in Kazakh).

In the following examples, sound compatibility is combined with emotionality and expressivity to attract reader's attention. A lot of such word combinations can be found in the story: reason for gossip, set tongues wagging, sapience, clever, bar of conscience.

The next short story written by S. Alzhikov is titled as the What is Better than Respect for Each Other? It is about a hard-headed man, who sets no value for anything. At first glance, Maylyton Tuktibayev is described highly positively. The reader, however, feels a sarcastic tone in the story and notices a significant difference between the reality and the happening events. The title phrase is repeated at the end of the story to intense the sarcasm. Maylyton Tuktibayev is characterized only with a positive connotation: The Head of our factory - Maylyton Tuktibayev - is a handsome, odious man. He is open, sincere and pure-minded like a good guy should be. No wonder, people say about him that he is kind and generous. Sweetheart, this hussar never says "not allowed" or "no". Many people in need were favored by him; he solves all issues directly on phone. Even glorious Atymtay Zhomart is not worthy to black his boots.

Doubt, caused by excessive praise, is increasing after reading narrator's words and the inner monologue.

R.A. Avakova (2003) defines the connotation as follows: Connotation is a meaning associated with nominative units. This meaning is, in fact, a combination of emotive and associative images, and stylistic semes showing character's attitude to the subject and speech conditions (Avakova 2003: 190).

A.Zh. Shalbayeva (2003) agrees with this scientific definition and states the following: Connotation is a component of lexicological meanings. Connotative component consists of three functional types: descriptive, expressive-evaluative and normative. Descriptive connotation involves information about the meaning of subjects and processes in a completely different aspect. For example, a sheep is described as quiet and docile creature; a cow - as a harmful one.

Expressive-evaluative connotation consists of information about the object evaluation. Evaluation is made in terms of positive and negative emotions. Normative connotation is determined by the communicative act and is characterized by euphemism, dysphemism, jargon, taboos, etc. Connotative macro-component, not included directly in the semantic word structure, performs the function of an additional semantic meaning (Shalbayeva 2003: 33-34).

The above characteristic is a positive expressive-evaluative connotation.

Satirists successfully use deixes-substitutes providing interconnection of sentences:

... Takan is also considered as a man in style, an open-hearted leader in this region. Only he has a key to all issues in trade management here.

...Kezdeke is also not a simple man. He has rented one of the local farms to his brother-in-law.

...If he comes, factory will be in trouble. If he denies to Kazdeken, he will lose his rich brother-in-law. It is similar to losing his God.

XLinguae, Volume 11, Issue 2, April 2018, ISSN 1337-8384, eISSN 2453-711X 
Demonstrative pronouns perform several functions here: narrator refers to a specific subject and draws attention to it by means of demonstrative pronouns. He draws attention to what is being said and what happened before.

Since demonstrative pronouns perform a role of the entire sentence and paragraph, they also contribute to brevity, eliminate unnecessary repetitions and, thereby, create a stylistically finished text (Maytinskaya 1969: 62).

Therefore, demonstrative pronouns performing the role of a substitute are also considered as the best method for eliminating repetition of names (people and places) and actions, and as binding units:

... Takan is also considered as a man in style, an open-hearted leader in this region. Only he has a key to all issues in trade management here. In the last sentence, pronouns here and he are logically connected to the word Takan and word combination in this region. The above substitutes also perform an interconnection function.

The function area of pronouns is wider primarily due to their lexical and grammatical features. As a rule, they replace words that define the subject and its actions... (Balakayev et al.1974: 136-137).

Based on the above passages, we can see that Maylyton Tuktibayevich's generosity is intended only for people, who have power and influence.

The words can respect, given in quotation marks in the last paragraph of the story, show the author's attitude to what is happening in the form of sarcasm.

Kazakh culture-specific words sut pisirim (time of milk boiling), siyr sauym (time to milk a cow), bie sauym (time to milk a horse) are used to define the periods of time. The author uses them to put special emphasis in a satirical context.

The short story called the Aydahanyn Bes Eshki (Kazakh: Aüдаваныңң бес ешкі word-play, originally bared from old Kazakh proverb айдаваның бес ешкі, ысққырызыц жер жарады - English: You have only five goats, but what a fuzz you are making over them) narrates about registrations that have been made in stagnant times. In this case, a goat is an object exposing the fact of registration. Moreover, there are also popular barbarisms: бөдірет - подряд (contract), used by big bosses (authority).

In the short story called The Price of the Neighbor, author criticizes women spreading gossips. The author describes a negative portrait of a woman with her harmful actions breaking peace of the young family, and shapes a hostile attitude towards them:

...A black, stout and butch woman looking like a knot has smacked her lips.

...The upturned lip has shrunk. Hostility and hatred for the man were on her face. Eyes with painted lashes starred angrily on young woman's face.

... Middle-aged woman smacked her lips again, and grinned sardonically with a sound of a bent old saddle.

... While the middle-aged woman grieved and sorrowed, fat red Sharipa crawled to her like a flea.

Women with different appearance are similar in their actions in the situation of someone's family discord. Their conversation involves a lot of elements of archaism and dysphemism, as well as introductory words. For example, bitch; wild woman; wiggling her hips; so stupid; talking rubbish; poor, spring chicken!; To the library, you say?; Hm-m, the poor thing...

Situational and communicative context reveals the image of each individual woman, Sattygul and Abila.

According to Syrgabike, occasional meaning has been created based on the folk proverb describing them very precisely: Modern women have short hair, but long ears. The proverb known as the Woman has long hair, but short mind obtains a new overtone as a proof that women have a big mouth.

In the short story called the Left With Nothing, author truly tells about the abominable 
behavior of farm workers, who managed to make a profit at the expense of poor shepherds. For example, animal technician named Kosher skillfully uses the moment to misappropriate income from shepherds' labor.

The man looked towards the fence, behind which young lambs were located.

-What is this?! - animal technician stared at Zhayleken.

-There are such findings sometimes. Kodiren ${ }^{l}$ might happen even in the field, my dear...

- Zhayleken is running in front of his guest like a cadet. - Hey, Nazeke, put on a new tablecloth,- he said to his wife, who entered the house with a large cooking pot. Kosherzhan will do for bloodletting, although it is a spring lamb.

There are dialects in the speech of old Varenik (1984): kodiren, cadet, spring. The Dialectological Dictionary of Kazakh Language introduces the following meaning of the word spring. In Kazakh language, used in Kyzylorda and Kostanay regions, as well as in Turkmenistan, spring means young crops on last year field. In Kyzylorda, this word can be used sometimes to describe an illegitimate infant. In the context, described by S. Alzhikov, this word is used to describe a found lamb. The word cadet is used to show suppleness.

The short story called the Deaf Without Bell was written in 1978, and published under the title No time in Saktapbergen Alzhikov's story-book titled Kuydirgi ${ }^{2}$ in 1991.

Boltaygul is one of the story characters. Her name is composed of Russian and Kazakh words: boltay (Russian: болтай - chatter) and gul (Kazakh: гул - flower: is a typical ending for Kazakh female names: Aygul, Nurgul, Zhanagul etc.). Such name shows Boltaygul out in her true colors.

Based on Boltaygul's telephone conversations, we can see that her interests are limited to daily gossip, domestic troubles, and beauty issues. According to the story, she trusted herself to her husband, who had a high job position. In the meantime, she let things slide at work and spent more time chatting on phone.

Boltaygul uses barbarisms, dialects, interjections and other unconventional word formations as well (mixed dialect involves both Kazakh and Russian words).

In the short story called the Smoke is Coming from the TV that is included in U. Uaydin's Vsyakaya Vsyachina book (Russian: "Всякая всячина”, which may be translated as Tutti-Frutti or All Sorts and Sundries, 1992), character named Ganura repeats Boltaygul's actions. The endings of these stories, however, are different: Boltaygul goes home to cook, and Ganura makes conclusion that endless conversations may overheat even a TV-set and a telephone. Thus, satirists clearly show bad habits of people by turning them into the objects of criticism.

In these short stories, humor appears in situations unexpected by readers.

The following short stories written by E. Dombayev are worth to be mentioned: the Desire, the Joke, the Father and Son, the Reliable Worker. In the first story that begins with a nominative sentence, talkativeness and curiosity of women are a subject to laughter; in the second story, these are relationships between the violent father and his son; the third story is about family and negative influence of the father on his son; the last story is about a bribe-taker, who still has been kept at his job thank to his patron.

The dialogue between women flirting with each other is funny in the Desire.

\footnotetext{
${ }^{1}$ Kazakh: қ̧одырен

${ }^{2}$ Kazakh: Күйдіргі
}

XLinguae, Volume 11, Issue 2, April 2018, ISSN 1337-8384, eISSN 2453-711X 
Dialogues with emotionally expressive color in their semantics are based on direct and associative meaning of words.

Metaphoric phrases have a great effect. For example, ilme soez, uly zhebe, zhuty-elinin tili (Kazakh: ілме сөз, ұль жебе, жұты-елінің тілі).

- It is better to be a wife than a diner!

- Eh, you live for people, you say!

In this case, author shows humor by reducing the word meaning.

In the short story called Joke, reality is shown by the contrast based on lexical and contextual antonyms: boy with a briefcase bigger than he is.

U. Uaydin's Vsyakaya Vsyachina was published in the cycles the Lyrical Stories, the Satirical Novel, the Humorous Stories, the Cut, the Jokes. In humorous short stories, writer sharply criticizes bad habits, such as drinking, destructive gossip, envy, whistleblowing, servility, brutality, bribery, aggrandizement, boasting. In the short story called the Got Pretty Brazen, Oktay, who is a whistle-blower, hypocrite and arrogant, has raised a scandal and confusion in the family and at work of his contemporary Doyr. As a result, Doyr also becomes a bully. The author conveys it with an associative meaning of the phrase at the beginning. Metamorphosis that happened with Doyr at the end of the day is expressed in his phrase: What a life, clear-unclear, reckless! The author uses double words to increase the dynamics showing the paradox of life. Doyr is not able to understand it.

In the Smoke is Coming from the TV, we can observe the image-bearing effect in the lexical-phraseological context with its emotional and expressive vocabulary, periphrasis, syncretism, with elements of spoken language and words with the opposite meanings.

The following tools are used in order to highlight the funny side of the story: periphrasis composed with syncretic formations (how many kilometers per second are there in the words; she got her face out of the phone; she just recovered from laughter; the face grumpy replied over her shoulder; two shoes are walking; she greeted TV; she communicated with cigarettes), expressive syntactic constructions (after chatting; turning her flat face; Ganura stopped talking in the middle of picking in her ear and grabbing up the phone; Tmat and I burst with laughter. Unable to bear this, we went out into the corridor and began to laugh there... and she started talking again in a frenzy) and vernacular words: crazy woman, women are the same, because ..., Get out, scum, don't mess up with me that increase the humorous coloring of the story.

The following proverb comes to our mind after reading the short story called the We Gave You an Apartment: If you are a nobleman, be modest. We learn the true nature of the trade union chairman Tastemirov through author's characterization and the inner monologue:

Tastemirov left the room blowing up his nostrils and stamping his feet. Hammering, he entered the room of the elder, whose name was Nurbay.

- If the chief or engineer calls, you run, but for me you have no time, as usual.

Do it for me, - Tastemirov asked with his steel voice the young woman with freckled face.

Wide-eyed Tastemirov began to clutter, blowing out his cheeks and sniffing.

Tastemirov was pleased only with himself, but not with life. He was selfsatisfied, able to do something and to speak nicely. However, he was good for nothing... Let him speak.

- Everybody is lucky. They get promoted sooner than I can think, and then swell with importance. I am independent, but taught by someone, who is young enough to be my son. I understand not less than others do. I am not stupid, I just have no support. That short man cannot say any word, but he is a chief engineer, he has a car. Big boss, you see, has put on a hat and a new pair of glasses. Our Make is also 
interesting. "Dauke, - he says, - you are sitting on the same place all your life". Would he better offer me to take his place, his car, but don't tell that only to please me: "Dauke can speak directly, everybody is afraid of him". If that is so, he could prepare me for his position. He is a cunning dog that's what he is. Wouldn't he keep that short man otherwise? We'll see, how he will manage!

With such words, he crossed few rooms.

- When you are called by the chief, party committee or the chief engineer, then you run. When I start speaking, you scream at the top of your lungs... "Wait, old man!.."

Tastemirov turned rusty and started talking behind Nupbay's back.

"Things" came up in his brain again.

- Where was the chief, what he was doing? Who will he support? What is chief engineer doing?

He had enough "collected facts" in his brain. He will have to open these facts during the next election meeting.

In D. Isabekov's Peace Keeper, we can see such appeal to one of the main characters Ardak:

By the way, we admitted you into the fellowship of kolkhoz ${ }^{3}$. Here is your work record card.

The author alternately uses formal and informal forms of the pronoun you (Russian pronouns: $b b l$ and $m b l$, respectively) in order to show the level of character's excitement. In this regard, we should refer to the opinion expressed by A.S. Adilova (2003) regarding the meaning of such pronouns used by A.S. Pushkin, M. Alimbayev and K. Myrza Ali.

According to the researchers, Kazakh literature and creativity of its representatives have been developed in the $60-80$ s of the last century.

In our case, there are substitutes binding the sentences. For example, Tastemirov left the room, blowing up his nostrils and stamping his feet. Hammering, he entered the room of the elder, whose name was Nurbay...). If the same words are repeated several times without using these substitutes, then it will result in tautology, and the connection between syntactic units will be lost. The pronouns used instead of nouns (deixis) have also performed the role of substitutes.

Substitute-deixis is used to avoid repetition. If there is no such a structure, then semantic connections are destroyed in the text.

The Issue of Debt is the next short story characterized by special word use. Blushed like a rose, Mikylys had changed his speech from polite "you are welcome" to rude "hey, you there".

Authors use direct and associative meaning of pronouns as idiomatic notions:

- Please, Sir. I have dropped my ticket, could pick it up for me?

- I'm not laying before every girl. Go away!

- We will do this by ourselves then, move your back.

- Nope, I like this place.

- I said, move your back!

- Nope. If I move, you'll take this warm place. I would not allow every girl to do this.

- Let us go forward then, we'll find another place.

- You will not find a seat!

${ }^{3}$ collective farm in the USSR

XLinguae, Volume 11, Issue 2, April 2018, ISSN 1337-8384, eISSN 2453-711X 
- What do you want from us?

- I want you to be polite while talking to me!

The author does not describe the anger of his character in details, but expresses it through well-chosen periphrasis. Epithet rude is generally used to show the nature of a rude and aggressive man. In many works, frequent use of the pronoun you covers a wide range of human's character: familiarity level mood, false modesty, etc. Repeated dialog phrases express the reaction of the opposite side.

In the last phrase, author reminds about the education of people, who should appreciate modesty and politeness.

\section{Conclusion}

To sum up, irony and humor created by Kazakh satirists are expressed by words with the opposite meaning and polysemantic word-play. The authors can use direct and associative meaning of formal and informal pronouns. In the analyzed linguistic passages represented by lexical and contextual antonyms, phonetic rhymes, amplification synonyms and rhetorical questions, convergence clearly shows an evaluation contrast between a character and the author.

We can also indicate the presence of convergence. Convergence is regarded as a combination of several stylistic techniques performing the same function in the text. Convergence, represented by lexical and contextual antonyms, phonetic rhymes, amplification synonyms and rhetorical questions, clearly shows the evaluation contrast between a character and the author. The reader makes his own opinion based on this contrast.

Mentioned writers consider the issues of similar nature and use the same language tools. There are no dialects in short stories written by O. Imanaliyev, E. Dombaev, U. Uaydin, but some particular dialects, used by S. Alzhikov, can be found in a dialectological dictionary. According to R. Syzdykova, the latter can be found in works written by T. Alimkulov. However, they are not required as a constant element of literary style.

\section{Bibliographic references}

ADILOVA, A.S. 2003. Sententiosity Linguistic and Stylistic Description. Almaty.

ARNOLD, I.V. 2002. Stylistics. Modern English language. Moscow.

ATTARDO, S. - RASKIN, V. 2017. Linguistics and humor theory. The Routledge Handbook of Language and Humor, 49.

AVAKOVA, R.A. 2003. Semasiology of Kazakh phraseological units. Almaty

BALAKAYEV, M. - ZHANPEYISOV, E. - TOMANOV, M. - MANASBAYEV, B. 1974. Kazakh language stylistics. Almaty.

BRAMLETT, F. (ED.). 2012. Linguistics and the Study of Comics. Palgrave Macmillan.

HODGART, M. 2017. Satire: Origins and principles. Routledge.

KOZHAKEEV, T. 1996. Satire's Fundamentals. Almaty.

MAYTINSKAYA, K.E. 1969. Pronouns in the languages of different systems. Moscow.

POTAPOVA, R. - POTAPOV, V. 2014. Associative mechanism of foreign spoken language perception (forensic phonetic aspect). In International Conference on Speech and Computer. Springer International Publishing, pp. 113-122.

RAPPORT, N. J. - STADE, R. 2014. Debating irony and the ironic as a social phenomenon and a human capacity. Social Anthropology.

SALIKHOVA, A.Z. 2001. Linguistic nature of comedian development in Kazakh. 2001. Almaty.

SHALBAYEVA A.J. 2003. Connotation of Linguistic Unit Semantics. KarMU khabarshys Journal 4: pp. 33-34.

SIMPSON, P. - BOUSFIELD, D. 2017. Humor and Stylistics. The Routledge 
Handbook of Language and Humor, 158.

SVEBAK, S. 2014. Humor. In Encyclopedia of Quality of Life and Well-Being Research (pp. 3048-3050). Springer Netherlands.

VARENIK, S.V. 1984. Comic expression in the language of the Soviet feuilleton. Kiev.

Words: 5848

Characters: 36881 (20,49 standard pages)

Bakyt Aitbaeva

Professor, Candidate of philological sciences

Manager by a department of Practical course of Kazakh language

Karaganda State University named after E.A. Buketov

Gulder-1-15-8, Karaganda,

Kazakhstan

aitbayeva.bakyt@gmail.com

Mukhamedkali Abduov

Doctor of Philology, dean of faculty of Kazakh literature

Karaganda State University named after E.A. Buketov

Gulder-1-15-8, Karaganda,

Kazakhstan

abduov_m@mail.ru

Kamhsat Tuleubaeva

Candidate of philological sciences, Associate professor

Faculty of Kazakh literature

Karaganda State University named after E.A. Buketov

Gulder-1-15-8, Karaganda,

Kazakhstan

k.toleubaeva@mail.ru

Marina Zhunusova

Candidate of philological sciences, Associate professor

Department of Practical course of Kazakh language

Karaganda State University named after E.A. Buketov

Gulder-1-15-8, Karaganda,

Kazakhstan

zhunusovamk@mail.ru

Almagul Ametova

Master of pedagogical sciences

Senior teacher of department of Practical course of Kazakh language,

Karaganda State University named after E.A. Buketov

Gulder-1-15-8, Karaganda,

Kazakhstan

a_amet71@mail.ru 